\author{
Dmytro Shyian \\ Simon Kuznets Kharkiv National University of Economics, Kharkiv, Ukraine \\ E-mail: dmytro.shyian@hneu.net \\ ORCID: https://orcid.org/0000-0002-0815-267X \\ Nataliia Ulianchenko \\ Department of Management and Taxation \\ National Technical University "Kharkiv Polytechnic Institute", Kharkiv, Ukraine \\ E-mail: nata.ulyanchenko@gmail.com \\ ORCID: https://orcid.org/0000-0002-3482-2454
}

\title{
Kateryna Honcharova
}

Department of Economics of Enterprise and Business Organization

Simon Kuznets Kharkiv National University of Economics, Kharkiv, Ukraine

E-mail: ekateryna.honcharova@i.ua

ORCID: https://orcid.org/0000-0002-0495-3031

\section{An innovative component in generating efficiency of sunflower production}

\begin{abstract}
The introductory part emphasizes that since 2004, Ukrainian agriculture has gradually begun to crank up production. This is largely associated with the growth of crop production, including sunflower. During 2004-2020, gross sunflower yield increased by 3.1 times, and yield capacity - more than double. Research methods involve grouping a complex of agricultural enterprises following the cost value per 1 ha of the sown area and sunflower yield. To classify the enterprises according to the level of innovative production, the authors have put forward a method for determining the coefficient of innovation. The object of the study comprises the agricultural enterprises of Kharkiv region. The results of grouping following yield rate have made it possible to establish a direct dependence between the cost value and sunflower yield. In a group of enterprises with an average yield of up to 15 centners/ha, costs amounted to $9653 \mathrm{UAH} / \mathrm{ha}$; in a group with a yield of 25.1-30 centners/ha - $14860 \mathrm{UAH} / \mathrm{ha}$; with a yield of more than 45 centners/ha - $27518 \mathrm{UAH} / \mathrm{ha}$. It has also been found that an increase in the rate of sunflower yield by 1 centner leads to an average profit increase of $307.9 \mathrm{UAH} / \mathrm{ha}$. The grouping of enterprises by the level of costs per 1 sown area of sunflower has made it possible to assume that the nature of the relationship of a grouping indicator with profit margin is characterized by a nonlinear function. It has been determined that this function has a maximum when the cost increases by $16960 \mathrm{UAH} / \mathrm{ha}$ and the amount of profit - by $6199 \mathrm{UAH} / \mathrm{h}$. The paper has also marked that under such cost value, the value of sunflower yield should be equal to 29.8 centners/ha. The practical approval of the methodological approach to determining the coefficient of innovative development of sunflower production has shown that this indicator objectively conveys the rate of use of innovations in the manufacturing process. Enterprises that had a coefficient of innovative development above 1 were characterized by a much higher level of yield, profitability, and production intensity.
\end{abstract}

\section{Keywords}

Production efficiency, sunflower yield, production intensity, maximum of function, coefficient of innovative development.

JEL: D22, D24, O13, Q24

DOI: https://doi.org/10.30525/2500-946X/2021-2-4

\section{Introduction}

Since 2004, Ukraine's agriculture has been gradually resuming production, which was declining during 19912003. The transition from the Soviet system, which was based on the principles of a planned economy and stateowned enterprises, to a market economy turned to be very difficult. In 2003, compared to 1990, agricultural production was reduced almost fourfold. However, both the absolute indicators of production and efficiency of enterprises dropped. Thus, during 1990-2003, the yield of grains and legumes decreased almost twice, sunflower and sugar beet - by about $30 \%$, the productivity of cows - by $45 \%$. All this is evidence of the profound systemic crisis that has engulfed the entire agricultural sector. Under such conditions, the vast majority of enterprises even did not try to use innovative technological and managerial developments. The salary level was very low, most enterprises fell into salary arrears for several months, workers quitted en masse.

However, starting from 2004, the situation has gradually begun to improve. First of all, it was an effect of positive changes in crop production. The gross output of this industry increased by 2.72 times in 2020 compared to 2003. This was largely because the gross yield of sunflower increased by 3.1 times in that period. It is worth mentioning that the progress was conditioned by an advance of sown areas and crop yield. It boosted from 11.2 centners/ha in 2003 to 20.6 centners/ha in 2020 . One should bear in mind that in 2020, most parts of Ukraine 
experienced a drought that negatively affected yields. In the better weather conditions of 2019, the average yield of sunflower was 25.6 centners/ha.

All these changes were the outcome of the introduction of innovative technologies, improvement of production intensity. Therefore, the authors decided to examine the factors which specified the rate of yield and efficiency of sunflower production drawing on the case of agricultural enterprises of Kharkiv region. The aim also involved assessing the level of innovation of sunflower production. The object of the study comprised the 2019 static data of agricultural enterprises of Kharkiv region. The considered set of enterprises was equal to 499 that secured data reliability.

\section{Brief literature review}

Both domestic and foreign scientists study the issues of an economic component of sunflower production from different perspectives by both domestic and foreign scientists. Kondratiuk (2013) notes that it is impossible to reckon on a high crop yield without using modern technologies for growing and processing sunflower, scientific substantiation of ways to increase the efficiency of its production. In another paper, Kondratiuk (2014) analyzes the impact of concentration on the efficiency of sunflower production. The scientist concludes that, on the one hand, excessive concentration leads to oversaturation of sunflower crops which, in turn, causes soil degradation and depletion, the emergence of diseases, and pests of crops. On the other hand, excessive enlargement causes irrational transportation of goods, increases transport costs, complicates enterprise management.

In order to raise the efficiency of sunflower seed production, Kontseba (2014) suggests paying heed to the reduction in the overall crop production costs that should become the basis for lowing the cost price as a whole. According to scientist's data, the reduction of overall production expenses on $1.0 \%$ profit per 1 ha of harvested area increases by $0.2 \%$, and the level of profitability - by $0.42 \%$. In Perebyinis's opinion (2014), efficient sunflower production is possible primarily as part of the sunflower subcomplex, which means the production, harvesting, storage, processing, and sale of sunflower seeds. According to research findings by Milanović and Stevanović (2012), there is no direct dependence between changes in sunflower prices in the current year and changes in sown areas in the coming year. According to the authors, a change in demand and consumption share in the oils market may be the reason for the above. Haydar held a similar view (2020). Strapchuk also considers the price factor significant (2016). After analyzing prices based on the data of more than 6000 enterprises of Ukraine, three clusters of enterprises were separated following the price level. From the authors' point of view, the findings can be used in forecasting prices and thus efficiency in the sunflower market of Ukraine.

\section{Research methodology}

At the first stage of the study, the grouping method following the value of sunflower yield was used. At the second stage, the grouping by costs per 1 ha of sown area was carried out that made it possible to identify various factors influencing the efficiency level of sunflower production. Modeling with linear and nonlinear functions was also applied to establish dependences and determine the optimal parameters of related indicators. The authors' methodical approach to set a coefficient of innovative production was offered, and its approbation was carried out at some enterprises.

\section{Results}

\section{The influence of sunflower yield on its efficiency}

One of the main factors that shape crop yields in the agriculture sector is production intensity. Therefore, the costs of 1 ha of the sown area were identified as factors influencing the yield rate (table 1 ).

By relying on research findings, the first conclusion that can be drawn concerns a close interdependence between the level of costs and yields. In the group of enterprises with an average yield of up to 15 centners/ ha, costs amounted to $9653 \mathrm{UAH} / \mathrm{ha}$, in the group with a yield of 25.1 - 30 centners/ha - $14860 \mathrm{UAH} / \mathrm{ha}$, with a yield of more than 45 centners/ha - $27518 \mathrm{UAH} /$ ha.

Its dependence is characterized by almost linear character (figure 1 ). It is conveyed by the equation:

$$
y=14.43+0,0009 x
$$

TABLE 1 The influence of crop capacity on the efficiency of sunflower production in agricultural enterprises of Kharkiv region in 2019

\begin{tabular}{|c|c|c|c|c|c|c|c|c|c|c|}
\hline Yield group & $\begin{array}{c}\text { Crop } \\
\text { capacity, } \\
\text { centner/ } \\
\text { ha }\end{array}$ & $\begin{array}{c}\text { Sown } \\
\text { area, } \\
\text { ha }\end{array}$ & $\begin{array}{c}\text { Costs } \\
\text { per } 1 \text { ha, } \\
\text { UAH }\end{array}$ & $\begin{array}{l}\text { Seeds } \\
\text { per } 1 \text { ha, } \\
\text { UAH }\end{array}$ & $\begin{array}{c}\text { Mineral } \\
\text { fertilizers } \\
\text { per } 1 \text { ha, } \\
\text { UAH }\end{array}$ & $\begin{array}{c}\text { Fuel } \\
\text { per } 1 \text { ha, } \\
\text { UAH }\end{array}$ & $\begin{array}{l}\text { Wages } \\
\text { per } 1 \text { ha, } \\
\text { UAH }\end{array}$ & $\begin{array}{c}\text { Depreciation } \\
\text { per } 1 \text { ha, } \\
\text { UAH }\end{array}$ & $\begin{array}{c}\text { Revenue } \\
\text { per } 1 \text { ha, } \\
\text { UAH }\end{array}$ & $\begin{array}{c}\text { Profitability, } \\
\%\end{array}$ \\
\hline up to 15 & 13.0 & 312 & 9653 & 1621 & 1581 & 1400 & 457 & 451 & 781 & 8.8 \\
\hline $15.1-20$ & 18.0 & 718 & 11752 & 1554 & 1729 & 1274 & 625 & 1022 & 4804 & 42.0 \\
\hline $20.1-25$ & 22.6 & 751 & 13536 & 1721 & 2218 & 1309 & 587 & 1187 & 4017 & 29.6 \\
\hline $25.1-30$ & 27.1 & 735 & 14860 & 1891 & 2374 & 1976 & 857 & 1417 & 5320 & 33.8 \\
\hline 30.1-35 & 32.4 & 594 & 18299 & 2132 & 3619 & 2032 & 851 & 1494 & 6492 & 33.5 \\
\hline $35.1-40$ & 36.9 & 746 & 18540 & 2382 & 3065 & 2156 & 1264 & 2108 & 8372 & 40.4 \\
\hline 40.1-45 & 42.2 & 548 & 20769 & 2595 & 4289 & 3086 & 1078 & 1690 & 9091 & 39.7 \\
\hline more than 45 & 51.4 & 662 & 27518 & 2756 & 4448 & 3940 & 683 & 1,676 & 12803 & 48.9 \\
\hline By region & 28.5 & 678 & 15938 & 1976 & 2705 & 1903 & 809 & 1413 & 6011 & 36.4 \\
\hline
\end{tabular}

Source: calculated using statistical reporting of enterprises 


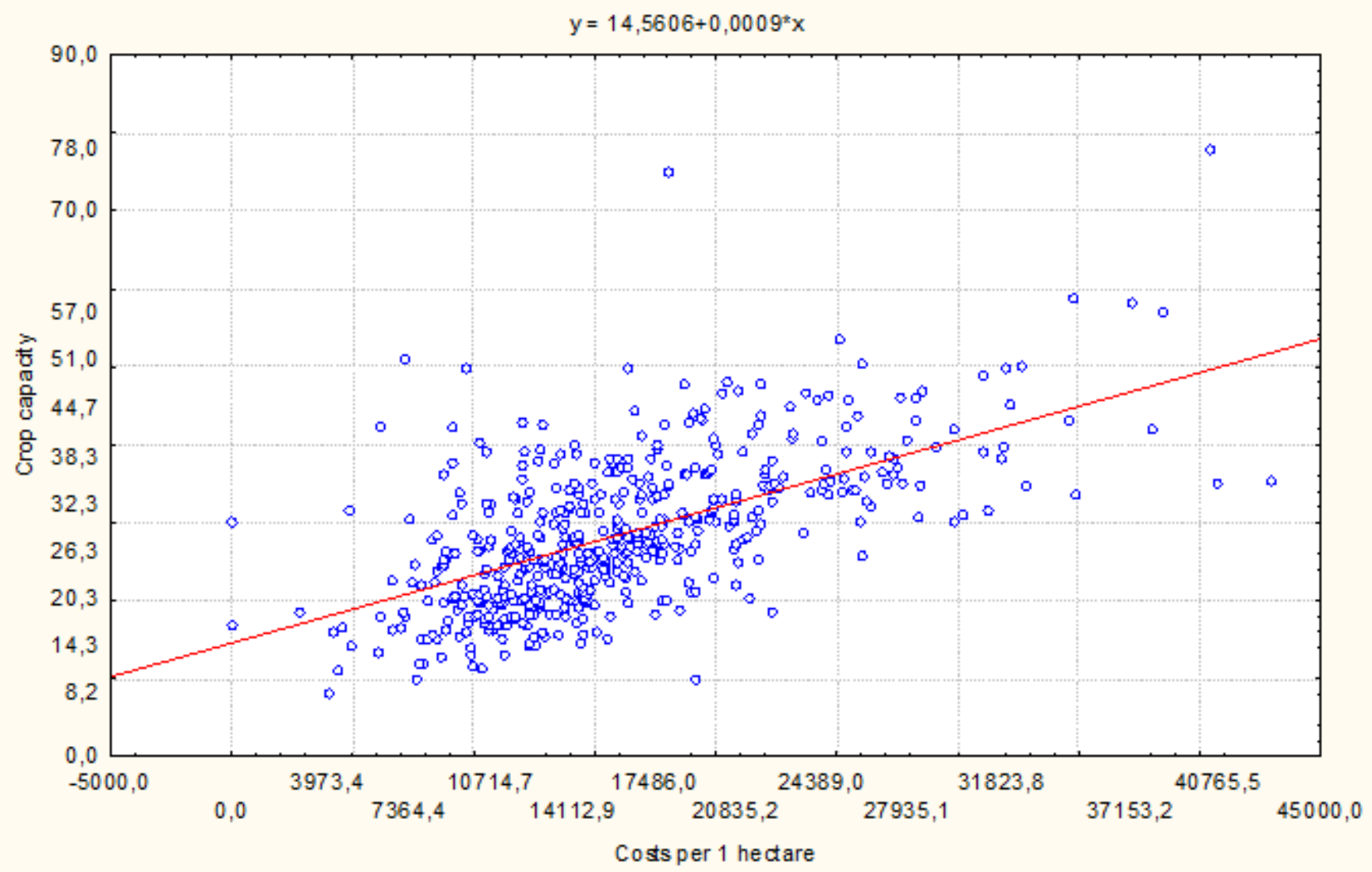

FIGURE 1 The influence of cost value per 1 ha of the sown area on sunflower yield in agricultural enterprises of Kharkiv region in 2019

Based on the function, one can say that the average increase in costs per 1 ha by1000 UAH results in yield growth by 0.9 centner.

The shift in individual expenditure items was also closely related to the average yield capacity of each group. Thus, the flow rate of mineral fertilizers in the group of enterprises with a yield of up to 15 centners/ha amounted to $1581 \mathrm{UAH} / \mathrm{ha}$, in enterprises with a yield of 25.1 30 centners / ha - $3619 \mathrm{UAH} / \mathrm{ha}$, with a yield of more than 45 centners/ha - $4448 \mathrm{UAH} / \mathrm{ha}$. In this case, the growth rate of expenses of mineral fertilizers should largely determine yield capacity. In our case, the growth rate of expenses of mineral fertilizers was above average than for all other costs. It should be emphasized that the "Depreciation" item showed the highest growth rates of costs. In the group of enterprises with a yield of up to 15 centners/ha, the average costs under the same item amounted to $451 \mathrm{UAH} / \mathrm{ha}$, in the group with a yield of 35.1-40 centners/ ha - $2108 \mathrm{UAH} /$ ha, or 4.7 times higher. At the same time, in other two groups, with the highest yield capacity, it was lower. However, the general trend has a distinctive character associated with a high growth rate in costs for this item.

The "Fuel" item is essential in terms of characterizing the level of innovative production. As a rule, a rising scale of expenditures for the relevant item is closely associated with the number of technological operations that must be carried out following particular technologies. Thus, the increase in costs for this item may point to a more complex nature of production, which includes additional technological operations. According to the calculation data, the situation appears clear: yield capacity increase correlates to cost increase for this expenditure item. Their absolute value varied from $1.400 \mathrm{UAH} /$ ha in the group of enterprises with a sunflower yield up to 15 centners/ha to $3.940 \mathrm{UAH} / \mathrm{ha}$ in a group with a yield of more than 45 centners/ha.

The "Wages" item has a special modification. Costs under this item per 1 ha of the sown area gradually increase from $457 \mathrm{UAH} /$ ha in the group with a yield of up to 15 centners/ha to $1264 \mathrm{UAH} / \mathrm{ha}$ in the group with a yield of 35.1-40 centners/ha, or 2.77 times larger. However, then they are reduced to the level of $683 \mathrm{UAH} / \mathrm{ha}$. In this case, from the authors' point of view, such figures may be explained by the higher level of labor productivity in the enterprises of the latter group that allows saving salaries. If the authors' assumption is false, one can argue that there are problems with efficient incentives for staff for higher yields during sunflower production.

The analysis also uses an indicator that characterizes production scale - a sown area. Therefore, one can state that in all groups of enterprises, except for the first, the scale of the sown area did differ significantly. The first group of enterprises with the lowest level of productivity has much smaller sown areas. However, the issue of whether the above significantly affects the generation of yields requires further research.

The research refers to below regarding the interrelation of yield capacity with other indicators of production performance, namely the amount of profit per 1 ha and profitability of production. As for the first of these 
indicators, there is evident interdependence between them which is characterized by the following function:

$$
y=-3344.8+307.9 x
$$

Based on the functional equation, it can be argued that an increase in sunflower yield by 1 centner leads to an average profit markup of $307.9 \mathrm{UAH} / \mathrm{ha}$.

Production profitability is a relative quantity. This affects its interrelation with other indicators, including yield capacity. In this case, there is no a vivid dependence on yield capacity, although the last group with the highest level of yield capacity showed the highest profitability among all groups. At the same time, it was lower in the group with a yield of 15.1 - 20 centners/ha, but not significantly (42.0\%).

\section{The influence of sunflower production intensity on}

\section{its efficiency}

In order to study the interdependence between the level of costs and production efficiency more thoroughly, the same enterprises were grouped by the criterion of the cost per 1 ha of the sown area (table 2). The whole set of enterprises was divided into five groups with the expenditure level ranging from $10.000 \mathrm{UAH} / \mathrm{ha}$ to over 25.000 UAH/ha.

The authors have already emphasized that there is a close correlation between yield capacity and costs. In turn, the scale of yield capacity has a positive effect on the profitability of sunflower production. However, the results obtained have somewhat different interrelations.

First, the dependence between the level of costs and productivity is also highlighted, but it is much less pronounced. In particular, the group with costs of up to $10.000 \mathrm{UAH} /$ ha showed the average yield of 20.6 centners/ha, the group with costs of 15.000.1-200.000 UAH - 29.9 centners/ha, and the latter group with costs of more than 25.000 UAH/ha 41.6 centners/ha. If one compares the present data with the data shown in table 1 , it can be found that yield difference between the marginal groups was almost 4 times and less than 3 times between costs. In table 2, the differences between costs of marginal groups are 3.55 times, and 2.02 times between yield indicators. It begs the question why? From the authors' point of view, grouping by yield capacity allows primarily marking the enterprises which use modern methods of conducting agricultural production in their economic activity, including on the basis of innovation, through optimizing expenses to achieve the maximum effect. Grouping by costs reflects the general situation related to production intensity. One group may include those enterprises which have high-efficient production and those which have low yield capacity and thus, low profits despite high costs. According to table 2, this fact is confirmed by negative dependence between costs and profitability of sunflower production. As for the interdependence with the profit margin, it was non-linear (Figure 2).

The function that characterizes this dependence has the following characteristics:

$y=265,69+0,6997 x-0,0000206 x^{2}(2)$

The maximum of this function involves an increase in costs by $16960 \mathrm{UAH} / \mathrm{ha}$ and in profit by $6199 \mathrm{UAH} / \mathrm{ha}$. If one substitutes the value of costs in function 1 , it results in the yield value equal to 29.8 centners/ha. In fact, the obtained parameters determine the most optimal values in terms of the "costs-yield" and "cost-profit" ratios according to the 2019 performance.

Determination of the innovation level in the development of sunflower production.

Thus, the question arises: is it bad or good if the parameters of an enterprise have values different from the optimal values set by the authors? It begs the question concerning the identification of those enterprises which can be characterized as ones that conduct production using innovative technologies and methods of business organization.

To answer these questions, the authors propose a relevant methodology. It is based on the comparison of the prescribed optimal indicators for the level of costs per 1 ha, profit per 1 ha and yield with the factual data of an enterprise. Thus, at the first stage, the relative indicators (coefficients) of the ratio for each indicator are determined.

$$
K_{i}=\frac{a_{i}}{a_{\text {opt }}}
$$

where

$K_{i}$ - ratio coefficient;

$a_{i}$ - the value of the i-th indicator;

$a_{\text {opt }}$-the value of the optimal indicator.

At the second stage, the three particular indicators are combined into a single indicator, which is proposed to be called the coefficient of innovative development of production, following the formula:

$$
\bar{K}=\sum_{i=1}^{n} \beta_{i}^{*} K_{i}
$$

where

$\bar{K}$ - coefficient of innovative development of production; $\beta_{i}$ - the share of the $i$-th indicator in rating.

The share of each indicator was set following the ratio of the standard deviation of each indicator to the sum of the

\begin{tabular}{|c|c|c|c|c|c|c|c|c|c|c|}
\hline $\begin{array}{l}\text { Group by cost } \\
\text { level, UAH / ha }\end{array}$ & $\begin{array}{l}\text { Costs } \\
\text { per } 1 \text { ha, } \\
\text { UAH }\end{array}$ & $\begin{array}{c}\text { Yield, } \\
\text { centners/ } \\
\text { ha }\end{array}$ & $\begin{array}{c}\text { Sown } \\
\text { area, } \\
\text { ha }\end{array}$ & $\begin{array}{c}\text { Seeds } \\
\text { per } 1 \mathrm{ha}, \\
\text { ha/UAH }\end{array}$ & $\begin{array}{c}\text { Mineral } \\
\text { fertilizers } \\
\text { per } 1 \text { ha, } \\
\text { UAH }\end{array}$ & $\begin{array}{c}\text { Fuel } \\
\text { per } \mathbf{1} \\
\text { ha, UAH }\end{array}$ & $\begin{array}{c}\text { Wages } \\
\text { per } 1 \text { ha, } \\
\text { UAH }\end{array}$ & $\begin{array}{c}\text { Depreciation } \\
\text { per } 1 \text { ha, } \\
\text { UAH }\end{array}$ & $\begin{array}{l}\text { Profit } \\
\text { per } 1 \text { ha, } \\
\text { UAH }\end{array}$ & $\begin{array}{c}\text { Profitability, } \\
\%\end{array}$ \\
\hline up to 10000 & 8546 & 20,6 & 466 & 1974 & 1438 & 1442 & 764 & 791 & 8136 & 80.0 \\
\hline $10000.1-15000$ & 12,638 & 24.7 & 793 & 1796 & 1950 & 1619 & 663 & 998 & 5905 & 42.7 \\
\hline $15000.1-20000$ & 17228 & 29.9 & 765 & 2189 & 3349 & 1858 & 1008 & 2032 & 5265 & 29.6 \\
\hline $20000.1-25000$ & 22171 & 36.8 & 532 & 3000 & 4824 & 3161 & 1184 & 2237 & 7419 & 35.9 \\
\hline more than 25,000 & 30351 & 41.6 & 561 & 3237 & 6151 & 4612 & 1447 & 2482 & 4930 & 17.7 \\
\hline By region & 15938 & 28.5 & 678 & 1976 & 2705 & 1903 & 809 & 1413 & 6011 & 36.4 \\
\hline
\end{tabular}

TABLE 2 The influence of costs per 1 ha of the sown area on the efficiency of sunflower production in agricultural enterprises of Kharkiv region in 2019

Source: calculated using statistical reporting of enterprises 


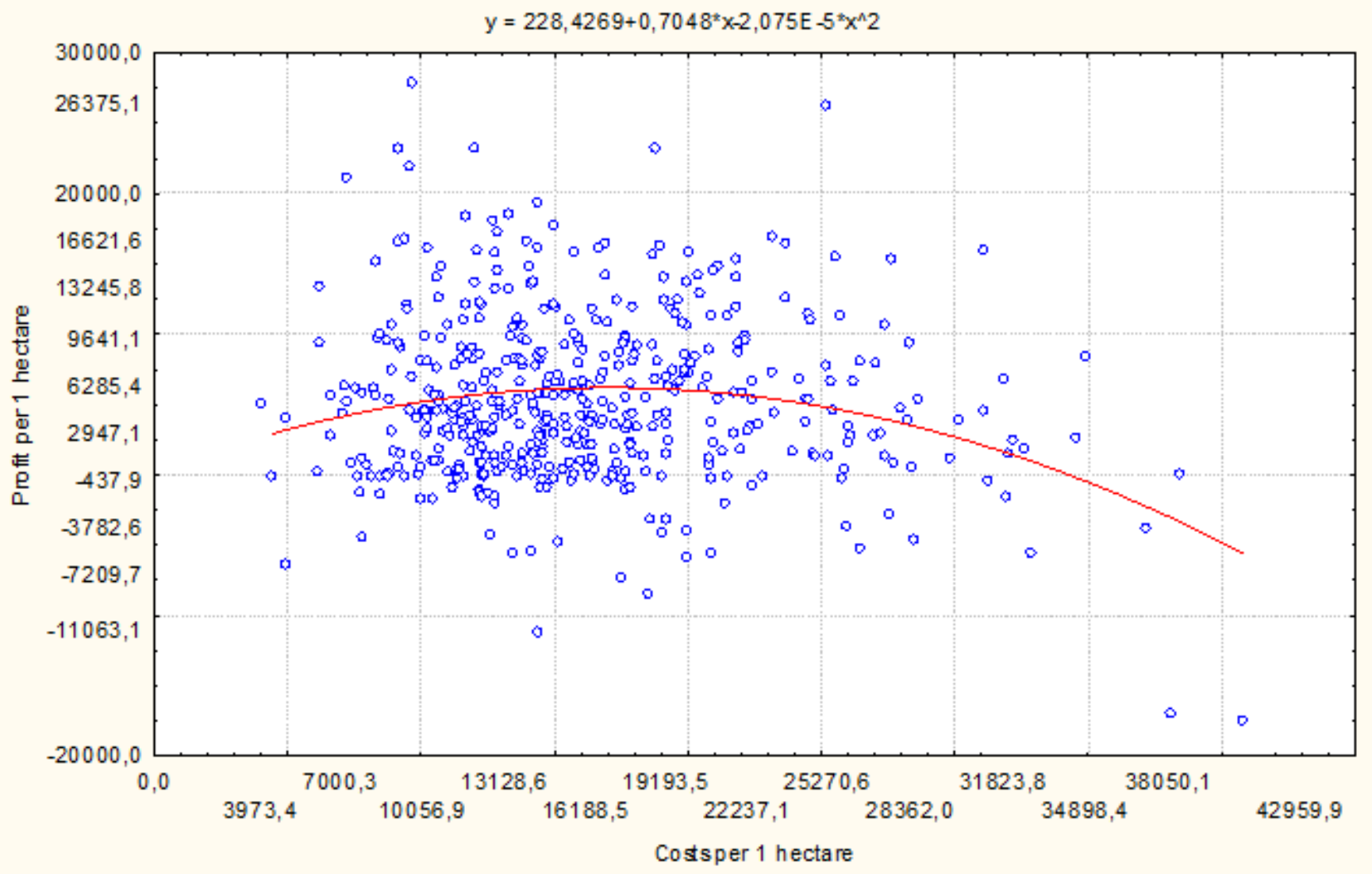

FIGURE 2 The influence of costs per 1 ha of the sown area on sunflower profit in agricultural enterprises of Kharkiv region in 2019

standard deviation of particular indicators following the formula:

$$
\beta_{i}=\frac{\sum \sigma}{\sigma_{i}} \div \sum \frac{\sum \sigma}{\sigma_{i}}
$$

where

$\sigma_{i}$ - standard deviation of the i-th indicator.

The purpose of this calculation is to minimize the impact of the variability of individual indicators on the coefficient of innovative development of production. Otherwise, a significant variation in individual indicators can significantly change the final result. The values of the coefficient of innovative development of sunflower production obtained in the relevant groups of enterprises according to the level of yield capacity are shown in table 3 .

TABLE 3 The coefficient value of innovative development of sunflower production depending on the yield capacity of agricultural enterprises of Kharkiv region in 2019

\begin{tabular}{|c|c|}
\hline $\begin{array}{c}\text { Yield group } \\
\text { to } 15\end{array}$ & \begin{tabular}{c} 
Coefficient of innovative development \\
\hline $15.1-20$
\end{tabular} \\
\hline $20.1-25$ & 613 \\
\hline $25.1-30$ & 711 \\
\hline $30.1-35$ & 914 \\
\hline $35.1-40$ & $-1,123$ \\
\hline $40.1-45$ & $(1215)$ \\
\hline more than 45 & 1,362 \\
\hline
\end{tabular}

Source: author's calculations
By relying on calculation data, one can state that yield capacity, as well as related indicators of costs and profits per 1 sown area, are closely correlated with the coefficient value of innovation-driven development. The outcome is expected and has economic logic. It is also proof that the coefficient proposed by the authors objectively reflects the innovation-related processes in sunflower production.

The authors also studied the way the coefficient value of innovative development of sunflower production is influenced by the indicators used under its calculation (table 4).

TABLE 4 Interrelation between the coefficient of innovative development and the level of efficiency and intensity of sunflower production in agricultural enterprises of Kharkiv region in 2019

\begin{tabular}{|l|c|c|c|c|}
$\begin{array}{l}\text { Coefficient } \\
\text { of innovative } \\
\text { development }\end{array}$ & $\begin{array}{c}\text { Number of } \\
\text { enterprises }\end{array}$ & $\begin{array}{c}\text { Yield, } \\
\text { centers/ } \\
\text { ha }\end{array}$ & $\begin{array}{c}\text { Costs } \\
\text { per 1 ha, } \\
\text { UAH }\end{array}$ & $\begin{array}{c}\text { Profit } \\
\text { per 1 ha, } \\
\text { UAH }\end{array}$ \\
\hline Up to 1 & 240 & 23.9 & 14159 & 4433 \\
\hdashline More than 1 & 181 & 38.1 & 19651 & 10233 \\
\hline
\end{tabular}

Source: authors' calculations

In this case, all enterprises were divided into two groups with the coefficient value of innovative development of sunflower production that is less than 1 and more than 1. The total number of enterprises was 421,240 of them had a coefficient value less than 1 , and 181 - more. The decrease in the enterprises' number in this calculation is explained by the fact that enterprises which suffered 
losses in the sunflower production were included. It is the second group of enterprises that tends to use innovative developments in production practice. This is evidenced by the values of indicators. In the group with the coefficient of innovative development more than 1 , the average sunflower yield amounted to 38.1 centners/ha compared to 23.9 centners/ha in the group with the coefficient less than 1 , the average cost per 1 ha of sown area - $14159 \mathrm{UAH} / \mathrm{ha}$ and $19651 \mathrm{UAH} /$ ha respectively, and the amount of profit is $4433 \mathrm{UAH} / \mathrm{h}$ a and $10233 \mathrm{UAH} / \mathrm{ha}$.

\section{Conclusions}

The study of the efficiency and innovation level of sunflower production on the example of agricultural enterprises of Kharkiv region allowed establishing the following. First, there is close interdependence between the yield capacity and costs per 1 ha of sunflower sown area. The yield scale largely determines the amount of profit per unit of the sown area. Secondly, the level of production intensity is non-linear due to the amount of profit per 1 ha of sown area. According to the 2019 figures, the maximum profit rate amounted to $6199 \mathrm{UAH} / \mathrm{h}$ a under costs of $16.960 \mathrm{UAH} / \mathrm{ha}$. Third, the proposed methodological approach to determining the coefficient of innovative development of production makes it possible to comprehensively consider both the level of efficiency and intensity in relation to the established optimal criteria.

The outcomes of practical approval of the methodological approach found that enterprises with the coefficient value of innovative development beyond 1 had a significantly higher yield, cost level and profit per 1 hectare of the sown area. All these indicators are solid markers of the level of both technological and organizational innovation of production. A similar methodological approach can be extended to other crops. This will make it possible to assess the state of innovative development of the entire enterprise comprehensively and, accordingly, the totality of enterprises in the region. In turn, such information may be of interest to government agencies and some suppliers and buyers.

Another essential position concerns the basis our agriculture relies on during its development. The conducted approbation gives ground to conclude that less than half of all enterprises engaged in sunflower production could be attributed to those which are characterized by the innovative nature of development. Other companies are likely to use outdated approaches to business organization and thus the technology of sunflower seed production. The findings can serve as a basis for a proposal for realizing the relevant state policy on the innovative path of agriculture development.

\section{References}

[1] Kondratiuk, N. V. (2013). Suchasni tendentsii vyrobnytstva nasinnia soniashnyku v silskohospodarskykh pidpryiemstvakh Kharkivskoi oblasti [Current trends in sunflower seed production in agricultural enterprises of Kharkiv region]. Visnyk KhNAU. Seriia: Ekonomichni nauky, 3, 157-162. (in Ukrainian)

[2] Kondratiuk, N. V. (2014). Kontsentratsiia yak chynnyk formuvannia efektyvnosti vyrobnytstva soniashnyku [Concentration as a factor in shaping the efficiency of sunflower production]. Visnyk KhNAU. Seriia: Ekonomichni nauky, 6, 243-250. (in Ukrainian)

[3] Kontseba, S. M. (2014). Shliakhy pidvyshchennia efektyvnosti vyrobnytstva nasinnia soniashnyku v rehioni [Ways to increase the efficiency of sunflower seed production in the region]. Visnyk KhNAU. Seriia: Ekonomichni nauky, 4, 313-323. (in Ukrainian)

[4] Perebyinis, V. I. (2014). Stratehichni napriamy udoskonalennia lohistyky i marketynhu nasinnia soniashnyku [Strategic directions for improving the logistics and marketing of sunflower seeds]. Visnyk KhNAU. Seriia: Ekonomichni nauky, 5, 48-54. (in Ukrainian)

[5] Milan R. Milanović \& Simo Stevanović (2012). Models of Regression of the Scope of Sown Areas and Purchase Prices of Oil Crops in Serbia, Economic Research-Ekonomska Istraživanja, 25:4, 1017-1032. DOI: https://doi.org/10.1080/133 1677X.2012.11517545

[6] Demirhan, Haydar (2020). dLagM: An R package for distributed lag models and ARDL bounds testing. PLOS ONE. 15. e0228812. DOI: https://doi.org/10.1371/journal.pone.0228812

[7] Strapchuk, S. (2016). Pattern formation of business conditions in domestic market of crop production. Baltic Journal of Economic Studies, 2(4). DOI: https://doi.org/10.30525/2256-0742/2016-2-4-79-83 